DOI: https://doi.org/10.30525/978-9934-26-020-9-4

Oleksii Miroshnychenko

$\mathrm{PhD}$ in Economics, Honored Economist of Ukraine Advisor to the Chairman of the Mykolaiv Regional Council

\title{
STABILIZATION OF THE NATIONAL CURRENCY RATE IN ENSURING ANTI-CRISIS DEVELOPMENT AND ECONOMIC SECURITY OF UKRAINE
}

\section{Summary}

The results of the study of the reasons for the decrease in the value of the national currency of Ukraine - the hryvnia are presented. A study of the theoretical foundations, political aspects and economic patterns of the devaluation of the hryvnia. The dynamics of consumer prices and the exchange rate of hryvnia to foreign currencies during 1992-2020 is studied. An analysis of the dynamics of the purchasing power of the hryvnia and the exchange rate is given. The inflationary nature of the positive dynamics of Ukraine's GDP is proved. Conclusions on the relationship between inflation and devaluation are presented. The necessity of ensuring the stability of the monetary unit in order to ensure anti-crisis development and increase the level of economic security of Ukraine is proved.

\section{Вступ}

Законом «Про національну безпеку України» сталий розвиток національної економіки, громадянського суспільства і держави для забезпечення зростання рівня та якості життя населення визнається одним із фундаментальних національних інтересів України [1].

При цьому на експертному рівні чітко визнається, що «фінанси не тільки опосередковують і відображають процеси, що відбуваються в економіці, на різних іiі рівнях, а й у низці випадків вони можуть провокувати i сприяти розповсюдженню кризових ситуацій, i поглиблення кризових явищ в економіці України вимагає об’єктивної та неупередженої оцінки з погляду фінансової безпеки фінансово-грошової політики, яка негативно позначається на стані забезпечення економічної безпеки нашої держави» [2, с. 273; 3, с. 135].

Дослідниками безпекою у грошово-кредитній сфері визначається «такий стан грошово-кредитної системи, який характеризується стабільністю грошової одиниці, доступністю кредитних ресурсів та таким рівнем інфляції, що забезпечує економічне зростання та підвищення реальних доходів населення» [2, с. 176].

Водночас під час вивчення питання знецінення національної грошової одиниці України увага широкого кола громадськості та більшості фахівців прикута передусім до зміни іiї обмінного курсу до інших валют, 
який часто помилково називають зростанням долара чи євро [4], при цьому навіть ураховуючи періодичні коливання курсів усіх світових валют, зростання обмінного курсу більшості з них відносно якоїсь однієї апріорі є падінням курсу саме цієї національної валюти, а не зростанням усіх інших.

Проблема загалом полягає у тому, що у вітчизняних реаліях, якщо навіть не розглядати періоди гіперінфляції, які випали на долю попередньої вітчизняної валюти - купоно-карбованця після введення у 1996 р. національної грошової одиниці України - гривні, процеси, що призводять до зниження іiі вартості, відбуваються 3 постійністю та невідворотністю добре відпрацьованого механізму.

\section{Розділ 1. Політико-економічні аспекти та закономірності процесу знецінення грошової одиниці України}

Насамперед варто зазначити: ми не розділяємо думки тих дослідників та менеджерів державного рівня, які надто високо оцінюють проведену свого часу «грошову реформу», погоджуючись із тими експертами, які вважають, що під час іï здійснення практично відбулася лише деномінація, або обмін купоно-карбованців на гривню, і не було досягнуто органічного поєднання грошової та фінансової політики $[3$, c. $128 ; 5$, c. 44$]$.

Саме це, на нашу думку, переважно і зумовило подальші кризові процеси з національною валютою. Як відомо, обмін купоно-карбованців на гривню відбувався за курсом 1 грн = 100 тис крб., та, відповідно, у 1996 р. встановився обмінний курс близько 1,8 грн/\$. Своєю чергою, різка зміна обмінного курсу відбулася у 1998 та у 1999 рр., коли офіційний курс гривні сягнув 3,5 та 5 грн/\$, у 2009 р. - 8 грн/\$, у 2014 p., коли обмінний курс НБУ наприкінці року досяг майже 16 грн/\$ та 20 грн/€, та в 2015 р., коли у лютому курс гривні перевищив відповідно 28 та 31 грн по відношенню до долара США та євро.

При цьому кожного разу відповідальність за «обвал курсу» здебільшого покладалася на НБУ, а причинами «чергової кризи» переважно визнавалися зовнішні чинники (у 1998 р. - падіння рубля, у 2009 р. - світова фінансова криза, у 2014 р. - російська військова агресія тощо). Зокрема, серед причин різкого падіння курсу гривні 2014-2015 pp. експертами називалися політична нестабільність, відставка уряду М. Азарова, невизначеність у подальших перспективах країни [6], роздуті державні витрати та високий дефіцит бюджету [7], безконтрольна емісія, економічні втрати на ринках СНД, «відсутність реальної фінансової допомоги 3 боку Заходу» [8], політична нестабільність у зв'язку з можливою відставкою уряду А. Яценюка, складна ситуація на Сході, ризик прямої інтервенції Росії, уведення військового податку, інформація про скорочення золотовалютних резервів НБУ, навіть дефолт Аргентини та обмеження США й 
Євросоюзом фінансування п'яти найбільших російських банків [9], а також ще майже нескінченна низка інших чинників.

Погоджуючись із тим, що зазначені чинники, як i безліч інших зовнішніх та внутрішніх причин, мають вплив на економічну ситуацію в Україні, ми вважаємо за необхідне довести дуже просту, на нашу думку, закономірність, яка полягає у тому, що якщо у разі будь-яких причин відбувається зростання цін, навіть за умов подолання негативного впливу цих чинників на обмінний курс, у подальшому неможливо буде уникнути «чергової кризи» та падіння обмінного курсу національної валюти внаслідок зниження іiі реальної купівельної спроможності. I у цьому плані продовжуємо наполягати на тому, що основною причиною періодичних «обвалів» гривні $\epsilon$ процес знецінення національної валюти, який у вітчизняних умовах, як і кризовий стан економіки, носить уже перманентний характер [10-12].

Доволі наглядно зазначені закономірності можна спостерігати, порівнюючи динаміку офіційного індексу інфляції (індекс інфляції, індекс споживчих цін характеризують зміни у часі загального рівня цін на товари та послуги, які купує населення для невиробничого споживання) та середньорічного обмінного курсу НБУ (рис. 1, за базовий прийнято курс 1992 p. 208 крб./\$; 2020 р.* - дані за I півріччя).

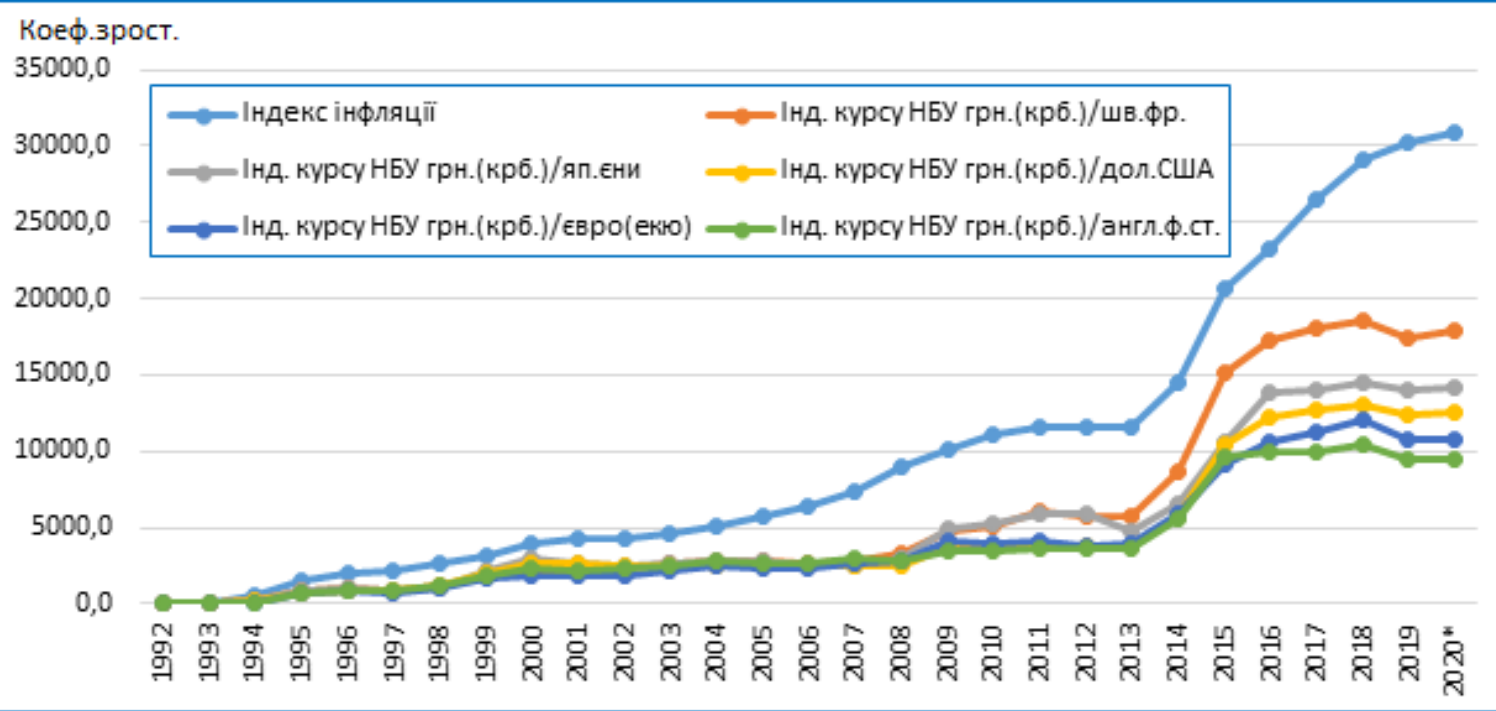

Рис. 1. Порівняльна динаміка споживчих цін та офіційного курсу гривні (до 1996 р. - крб.) до іноземних валют у 1992-2020 рр.

Зрозуміло, що при цьому коливання цін і курсу гривні зумовлювалося безліччю різних чинників у відповідних періодах, серед яких і зовнішні фактори, і внутрішні, такі як урядова політика і дії НБУ, врожайність зернових та інших сільськогосподарських культур, світові та внутрішні ціни на метал, хімпродукцію, нафту та нафтопродукти, інші енергоносії 
тощо. При цьому ми бачимо й те, що активність НБУ переважно спрямована на основні для України валюти - євро (до 1999 р. - екю) та долар США, що дає змогу курсу інших валют бути більш наближеним до динаміки реального знецінення гривні.

Неважко помітити, що реальне знецінення гривні (навіть незважаючи на явне заниження офіційно затвердженого індексу інфляції) значно перевищує динаміку обмінного курсу, створюючи підстави для подальшої нестабільності національної грошової одиниці (рис. 2). Таким чином, можна дійти висновку, що кожного разу процес зміни обмінного курсу носив об'єктивний характер і був наслідком реального знецінення національної грошової одиниці. I він не міг увесь час компенсуватися намаганнями НБУ стримувати валютний курс лише за рахунок активних операцій на валютному ринку.

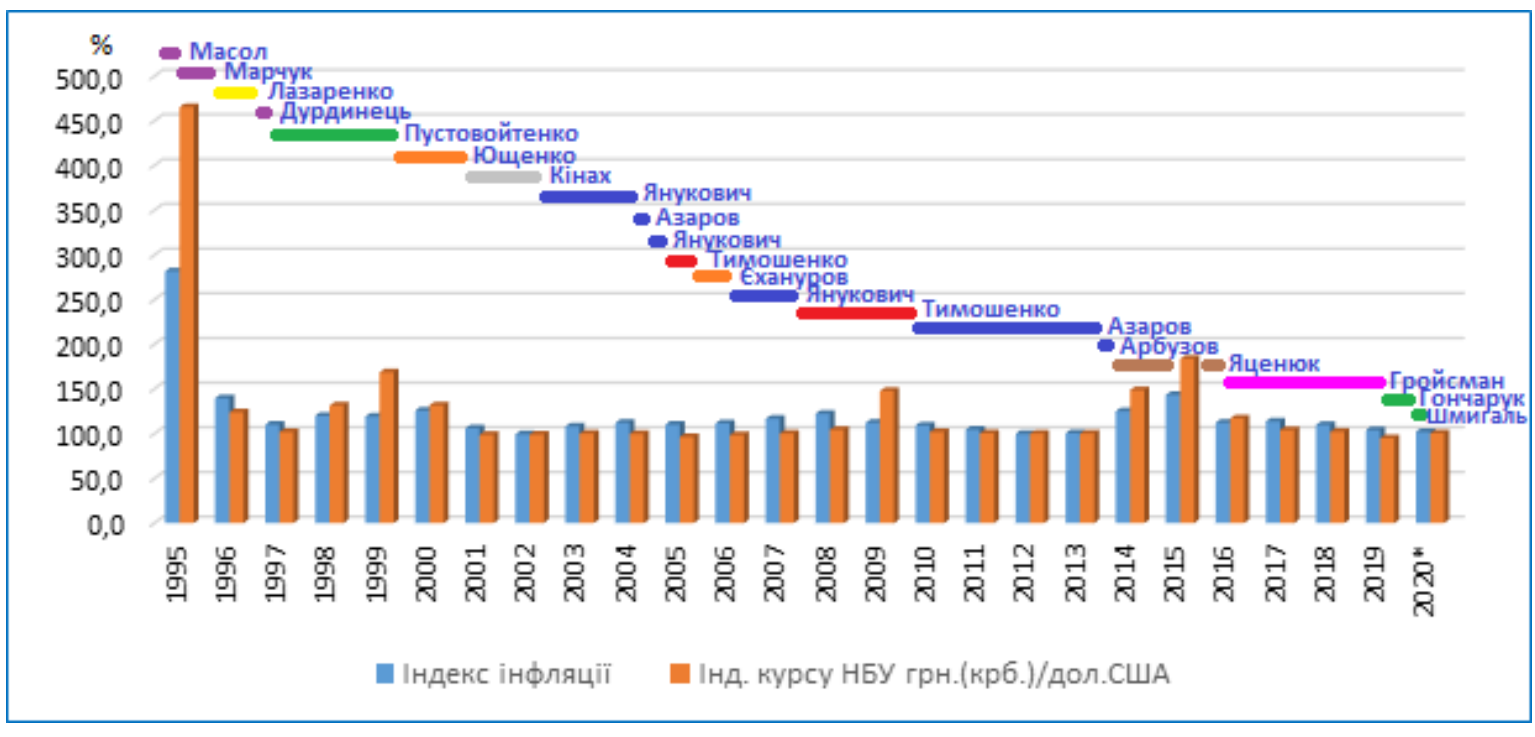

Рис. 2. Порівняльна динаміка індексу інфляції та офіційного курсу гривні (до 1996 р. - крб.) до долару США у 1995-2020 pp.

Зокрема, аналізуючи різке падіння курсу національної валюти десятирічної давнини, автор у той час зазначав, що «воно $\epsilon$ закономірним наслідком зменшення купівельної спроможності гривні за період із середини 1998 р., коли обмінний курс сягнув близько 4,5 грн за 1 дол. США» та «у зв'язку із тим, що з тих пір гуртові та роздрібні ціни в Україні зросли в середньому в 1,5-2 рази, а на деякі предмети споживання зростання цін значно перевищило цей рівень», «абсолютно закономірним є зниження обмінного курсу гривні внаслідок зменшення iii купівельної спроможності» [13]. При цьому варто підкреслити, що внаслідок недостатньої розвиненості ринкових механізмів українська економіка набагато менше постраждала від впливу світової фінансової кризи, ніж країни з розвиненою ринковою економікою, і навіть Росія, 
але «постійні нагадування Тимошенко про «світову фінансову кризу» для виправдання власних прорахунків i підвищення рейтингу напередодні дострокових виборів принесли навіть більшу шкоду вітчизняній економіці, ніж сама криза, оскільки, як зазначалося, з одного боку, спонукали громадян до вилучення депозитів i вкладення заощаджень у готівкову валюту інших держав, з іншого - продавців до збільшення цін у розрахунку на очікувану інфляцію. I таким чином очікувана інфляція стає реальною...» [14].

Можемо впевнено стверджувати, що такий самий процес відбувся і впродовж 2010-2014 pр., зумовлюючи обвал курсу гривні та, відповідно, кризові явища 2014-2015 рр. Наведені аргументи дали автору змогу того часу наголосити, зокрема, на тому, що «відверто програною урядом битвою, що на тлі політичних негараздів якось не привернула уваги громадськості, а скоріше і самого уряду, стало значне зниження купівельної вартості національної валюти весною поточного року внаслідок спочатку допущення спекулятивного зростання споживчих цін, потім такого ж безпідставного зростання вартості пального, наслідком якого стало чергове зростання цін уже внаслідок зростання вартості транспортних витрат. У такій ситуації зміна обмінного курсу гривні $є$ закономірною навіть без урахування інфляційних очікувань населення внаслідок політичної нестабільності. I штучно занижений офіційний рівень інфляції та стримане за рахунок діяльності Нацбанку відповідне зниження обмінного курсу у будь-якому разі не можуть уважатися вирішенням проблеми, оскільки i значне зниження купівельної вартості національної валюти, i, відповідно, зменшення реальних доходів населення відбулося реально, а не на папері» [15].

У 2014 р. дії Національного банку фактично відтермінували i, відповідно, уповільнили динаміку падіння обмінного курсу гривні (січень - 7,99 грн/\$, лютий - 8,66, березень - 9,92, квітень - 11,63, травень - 11,64, червень - 11,81, липень - 11,75, серпень - 12,95, вересень - 13,02, жовтень - 12,94, листопад - 14,7, грудень - 15,7 грн/\$), але у подальшому саме НБУ «виявився крайнім» у цій ситуації.

У результаті, незважаючи на політичну перемогу, за оцінками дослідників, з якими важко не погодитися, «після Євромайдану жителі України стали реально бідніше у декілька разів, відбулася девальвація національної валюти, що призвела до скорочення реальних доходів населення» i, своєю чергою, до чергової кризи та спаду національної економіки [16].

\section{Розділ 2. Інфляційно-девальваційний механізм знецінення української гривні}

Фактично спостерігаються кілька періодів, що відрізняються між собою кількісними характеристиками, але мають схожий характер динаміки (рис. 2): період зниження обмінного курсу гривні, коли 
динаміка індексу обмінного курсу перевищує динаміку індексу інфляції (1995 р., 1998-2000 pр., 2009 р., 2014-2016 рр.), змінюється кількарічним періодом, коли зростання споживчих цін перевищує динаміку обмінного курсу (1996-1997 рр., 2001-2008 рр., 2010-2013 рр., 2017-2019 рр.), наслідком якого знов стає падіння обмінного курсу. Використання під час дослідження такого показника, як індекс споживчих цін, пояснюється також тим, що в умовах сучасної економічної ситуації, що склалася в Україні, більшість населення витрачає значну частку доходів домогосподарств саме на поточні витрати (продукти харчування, комунальні платежі, вартість проїзду, ліки, одяг, взуття тощо), що значною мірою формує інфляційні очікування населення, і коливання цін на елітні авто чи нерухомість для цієї переважної більшості населення не має особливого значення.

Відповідні закономірності спостерігаються i під час аналізу показників динаміки ВВП (рис. 3). При цьому ми бачимо, що процеси, які призводять до зниження вартості національної грошової одиниці України, як це вже підкреслювалося, відбуваються із «завидною постійністю» та невідворотністю добре відпрацьованого механізму. I саме механістичність зазначеного явища та його негативний вплив на стан економіки у цілому та розвиток підприємницького сектору викликають найбільшу занепокоєність.

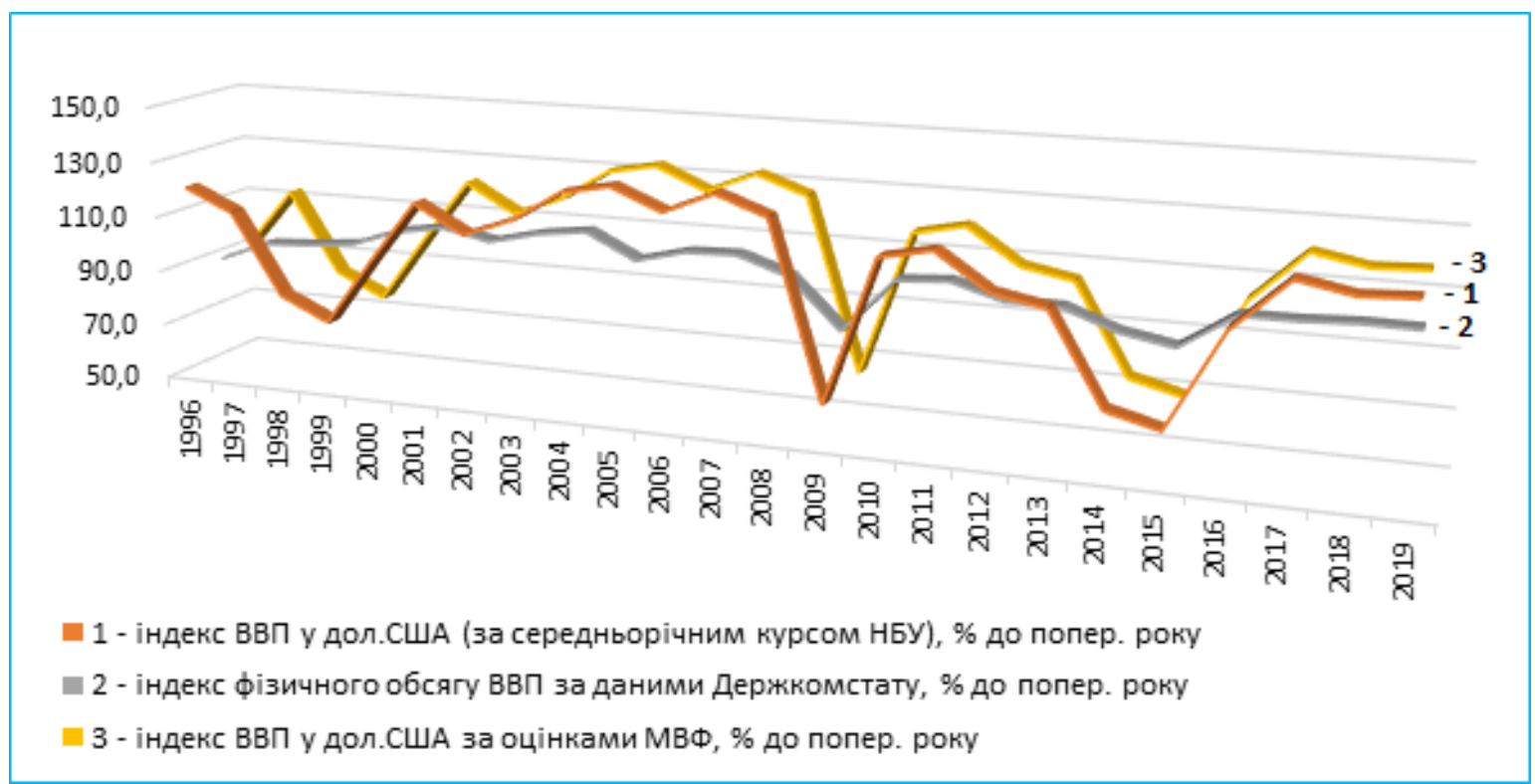

\section{Рис. 3. Порівняльна динаміка показників ВВП упродовж 1996-2019 рр.}

Також варто відверто визнати й те, що реальне зростання цін у цей час значно перевищує офіційний рівень інфляції, який постійно штучно коригується на вимогу урядових зверхників незалежно від їх політичної 
приналежності. Зокрема, ніяк не можуть уважатися наближеними до реальності показники індексу споживчих цін у 2010-2013 рр., що становлять відповідно 109,1, 104,6, 99,8 та 100,5, притому, що щомісячне зростання цін у ці роки часом перевищувало зазначені «річні» показники.

Показовим у цьому плані був і сам 2014 р., коли, незважаючи на те що споживчі ціни виросли більше ніж удвічі, офіційний індекс споживчих цін «був визначений» на рівні: 0,2\% - у січні, $0,6 \%$ - у лютому, 2,2\% у березні, 3,3\% - у квітні, 3,8\% - у травні, $1,0 \%$ - у червні, $0,4 \%$ у липні, $0,8 \%$ - у серпні, 2,9\% - у вересні, 2,4\% - у жовтні, 1,9\% у листопаді, 3,0\% - у грудні. Тобто формально знецінення національної грошової одиниці впродовж 2014 р. становило «лише» 24,9\%, що ніяк не відповідає дійсності і, відповідно, знайшло підтвердження й у «падінні» обмінного курсу.

За аналогією із загальновідомим принципом роботи двигуна внутрішнього згорання (впуск - засмоктування в циліндр горючої суміші через впускний клапан; стиснення після закриття впускного клапана рухом поршня горючої суміші, що при цьому нагрівається; робочий хід - підпалювання електричної іскрою свічки стиснутої горючої суміші, внаслідок чого сила тиску розпечених продуктів горіння штовхає поршень, рух якого передається колінчастого валу, за допомогою повороту якого і проводиться корисна робота; вихлоп викидання відпрацьованих продуктів згоряння через випускний клапан) процес знецінення гривні може бути описаний так само:

- поступове знецінення гривні через зростання цін;

- подальше падіння обмінного курсу національної грошової одиниці внаслідок зниження їі купівельної спроможності;

- різке зростання цін (i, відповідно, черговий етап знецінення гривні) внаслідок зміни обмінного курсу;

- подальше повторення представленого «циклу».

При цьому варто зазначити, що впродовж даного «інфляційнодевальваційного циклу» зниження купівельної спроможності гривні відбувається фактично двічі: спочатку внаслідок зростання цін за незмінності обмінного курсу, і потім, коли обмінний курс нібито «наздоганяє» реальне зниження купівельної спроможності національної грошової одиниці, ціни зростають ще раз, уже внаслідок зміни обмінного курсу. Тобто спочатку інфляційний процес виступає як причина девальвації національної валюти, а потім уже девальвація спричиняє інфляцію; у технічному плані можна було б казати навіть про винахід певного «вічного двигуна», наслідком безповоротної у свої механічності дії якого є «згоряння» національної грошової одиниці та, відповідно, подальша поступова руйнація економіки України.

Показовим у цьому плані $є$ аналіз динаміки фактичного (фізичного) обсягу ВВП із його динамікою у вартісному еквіваленті, зокрема на 
рис. 4 доволі чітко спостерігаються визначені періоди (1996-1997 рр., 2001-2008 p., 2010-2013 pp., 2017-2019 рр.), коли внаслідок того, що показники динаміки цін перевищують динаміку обмінного курсу, за мінімальної динаміки фізичного обсягу ВВП відбувається його зростання у вартісному еквіваленті, як у гривні, так і в інших валютах.

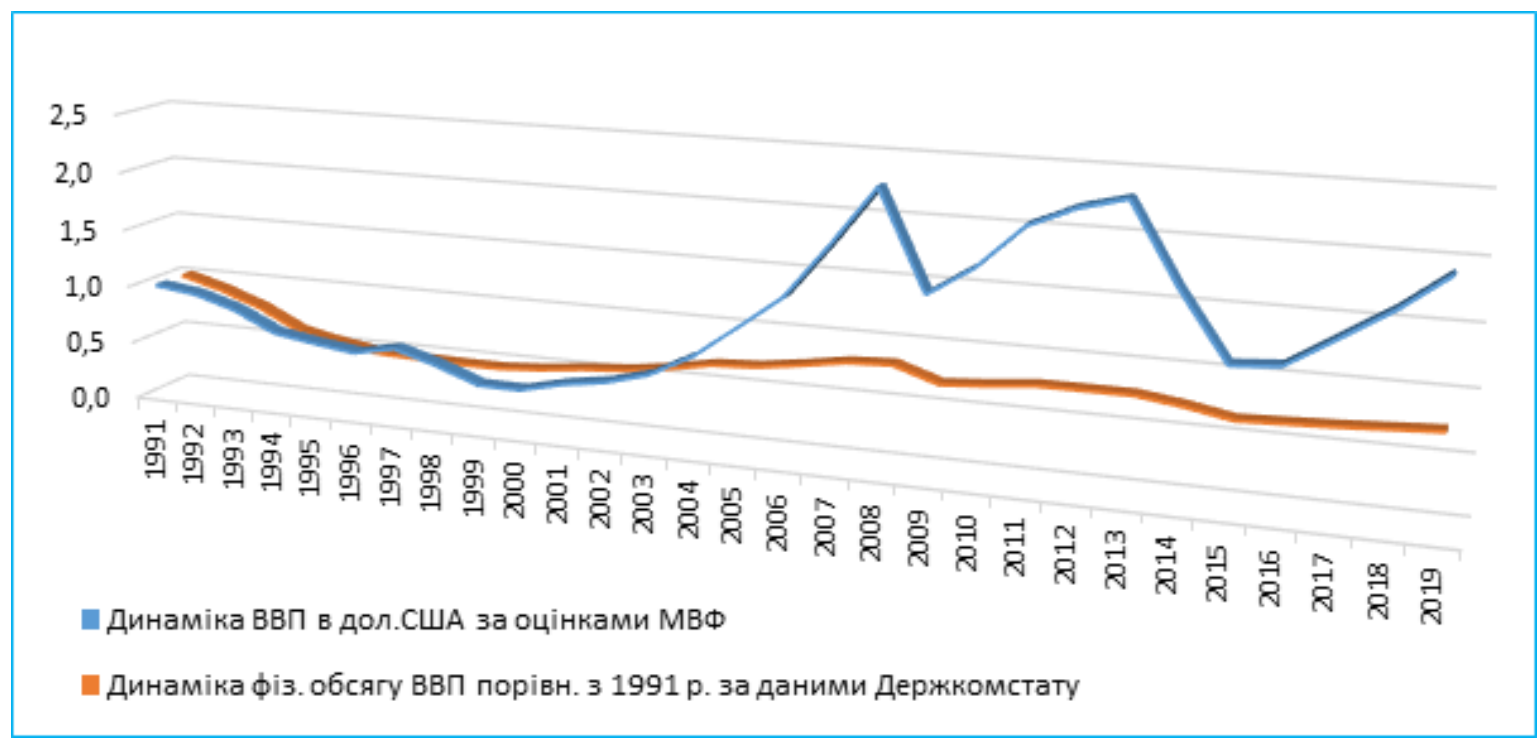

\section{Рис. 4. Порівняльна динаміка індексу інфляції та офіційного курсу гривні (до 1996 р. - крб.) до долару США у 1991-2019 рр.}

Таким чином, на жаль, ми маємо констатувати, що переважна частина вітчизняних «досягнень» щодо зростання ВВП має відверто штучний, «дутий» інфляційний характер, що представники експертного середовища визначали ще у 2004 р. на початку цих урядових «експериментів», які продовжуються до цього часу, незважаючи на численні зміни самих урядовців [17]. При цьому, враховуючи наявність явного «уточнення» (у бік мінімізації) офіційних даних щодо рівня інфляції і незначні показники позитивної динаміки фізичного обсягу ВВП, можливо навіть зробить припущення щодо його фактичного зменшення не лише впродовж 2009 та 2014-2015 рр., але й низки інших років, коли ці незначні показники статистичного зростання ВВП також досягалися за рахунок маніпуляцій з інфляційним складником. I, таким чином, саме в роки, коли відбувався «обвал» обмінного курсу, застосування таких «корегувань» виявлялося марним чи недоцільним (або ж недостатнім, щоб «перекрити» реальне падіння ВВП), що, зокрема, і призвело до спроб закрити статистичну інформацію щодо падіння ВВП у 2009 р. [18].

Варто також підкреслити, що у тому разі, коли відбулося «підпалювання стиснутої горючої суміші» (фактичне зниження купівельної спроможності національної валюти), тоді «вибуху», тобто 
падіння обмінного курсу, уникнути вже неможливо. I питання може стояти лише про його відстрочення або мінімізацію наслідків, що і може бути досягнуто за умов відповідних дій уряду, включаючи, зокрема, й операції Національного банку. У разі ж скорочення часових періодів прояви зазначених «механістичних закономірностей» можуть призвести до повернення у часи гіперінфляції, яка не лише повністю знищила купоно-карбованець як грошову одиницю, а й фактично зруйнувала значну частину економіки України. При цьому важливо підкреслити, що основною «проблемою» купоно-карбованця виявився не слабкий технологічний захист, а його незахищеність від непрофесійних дій тогочасного державного топ-менеджменту.

Щодо ж «іскри» - каталізатора, що активізував процес падіння обмінного курсу, то у вітчизняних умовах він має не стільки економічний, скільки переважно політичний характер, зокрема у 2009 p. каталізатором процесу девальвації гривні виступило поєднання світових кризових явищ та організованої на урядовому рівні активної спекуляції на внутрішньому валютному ринку України, спочатку на зменшення курсу долара США, а потім на його збільшення, з наслідками яких НБУ реально не зміг упоратися [12].

\section{Розділ 3. Економічні та суспільно-політичні аспекти стабілізації курсу національної валюти в забезпеченні перспектив антикризового розвитку та економічної безпеки}

Як класиками економічної науки, так і сучасними дослідниками до основних функцій грошей апріорі відносяться такі функції, як засіб заощадження [19, с. 186; 20, с. 264], засіб збереження цінності [21, с. 88-92], засіб накопичення [22, с. 45], засіб накопичення (засіб заощадження та засіб збереження вартості) [23, с. 13]; зручна форма накопичень [24, с. 128], засіб збереження та накопичення цінності [22, с. 49], засіб утворення скарбів [25, с. 104-156], засіб накопичення (заощадження, збереження багатства, збереження цінності [26, с. 57].

Не поглиблюючись у трактування відмінностей у підходах авторів різних концепцій, відзначимо, що динамічний розвиток економіки, різноманітність і ускладнення форм взаємодії суб'єктів ринку зумовлюють й істотні зміни змісту функції збереження цінності. Варто погодитися 3 тими авторами, які зазначають, що якщо раніше, в епоху золотих грошей, функція накопичення грошей була достатньо простою і навіть механістичною, то сьогодні вона невпізнанно ускладнилася. За часів класичного капіталізму грошово-кредитна сфера та грошовий обіг грали допоміжну роль і виконували обслуговуючі функції, у сучасному ж світі гроші перетворилися на рушійну силу економіки, а фінансовий сектор став самостійним елементом економічної системи держав [22, с. 47]. При цьому в умовах сучасної економіки обов'язковим атрибутом постає інфляція, тому актуальним стає не лише збереження 
або накопичення грошей, а й збереження їхньої купівельної спроможності (вартості, цінності), і грошова політика держави та бізнесово-управлінські стратегії, спрямовані на забезпечення економічного розвитку, будуються на необхідності максимально повної реалізації саме цієї функції грошей.

Стосовно ж національної валюти України - гривні, то варто визнати, що їй функція збереження вартості (цінності), на жаль, не була притаманна від самого початку ії введення, i, відповідно, цю функцію в українській економіці за гривню виконують грошові одиниці інших країн. До речі, більшість населення України, навіть та його частина, яка не надто розуміється на теорії грошей та особливостях національної фінансово-грошової політики, зробила свої висновки й уже традиційно віддає перевагу у зберіганні готівкових коштів саме у доларах США чи євро. Така ситуація спостерігається не лише в Україні, зокрема російськими науковцями також визнається, що фінансово-банківська система РФ базується на змішаній системі грошового обігу (рублеводоларова), причому «долар бере на себе такі функції, як засіб накопичення, і все більш значною мірою як засіб платежу» [27, с. 172].

У цьому плані ми не можемо погодитися 3 позицією тих урядовців та представників експертного середовища, які стверджують, що у сучасних умовах стабілізація національної валюти є невигідною для економіки країни, пояснюючи це, зокрема, тим, що у зв'язку зі зменшенням експорту в Росію українські виробники вимушені освоювати нові ринки, i «укріплення гривні на цьому тлі не піде на користь» [9], і солідарні 3 науковцями, які вважають, що будь-яке суттєве перевищення обмінного курсу $є$ «досить серйозною проблемою», оскільки наслідком такого випадку стає ланцюгова реакція з дестабілізації економіки [6].

При цьому не можна не пригадати й позицію «однієї 3 найвпливовіших жінок світу 2019 року за версією Financial Times» В. Гонтаревої, яка, перебуваючи на посаді голови НБУ, під час виступу у Верховної Ради заявляла, що «Національний банк відповідає за інфляцію, цінову стабільність і фінансову стабільність у державі» $\mathrm{i}$ «прогнозування курсу гривні та боротьба 3 фундаментальними причинами девальвації перебувають поза полем відповідальності регулятора» [28].

Варто підкреслити, що Конституцією та Законом «Про Національний банк України» чітко визначено, що НБУ є особливим центральним органом державного управління, основною функцією якого «є забезпечення стабільності грошової одиниці України» $\mathrm{i}$ «під час виконання своєї основної функції Національний банк має виходити 3 пріоритетності досягнення та підтримки цінової стабільності в державі» [29, ст. 99; 30, ст.ст. 2, 6].

Своєю чергою, забезпечення проведення фінансової, цінової, інвестиційної та податкової політики Конституцією України покладено 
на Кабінет Міністрів [29, ст. 116]. При цьому Національний банк у межах своїх повноважень сприяє фінансовій стабільності, у тому числі стабільності банківської системи (за умови, що це не перешкоджає досягненню цінової стабільності), а також додержанню стійких темпів економічного зростання та підтримує економічну політику Кабінету Міністрів України за умови, що «це не перешкоджає ціновій та фінансовій стабільності) [30, ст. 6].

Тобто, згідно із законодавством, НБУ має забезпечувати стабільність грошової одиниці та сприяти ціновій і фінансовій стабільності, що зовсім не співпадає з оприлюдненою його головою позицією. Хоча, своєю чергою, позитивним $є$ те, що і визнання керівництвом Нацбанку наявності «фундаментальних причин девальвації», безпосередньо пов'язаних із ціновою стабільністю, є певним прогресом.

Маємо лише пожалкувати про те, що так і не відбулося формування антикризового «технократичного» уряду 3 політично незаангажованих професійних менеджерів, про який так багато говорилося і який замість того, щоб займатися політичною саморекламою, шляхом сприяння активізації економічних процесів та розвитку підприємницькому сектору мав би втримати національну економіку від скочування у чергову «економічну кризу» [31].

Українським урядовцям варто повчитися тому, як прикладають зусилля для підтримання стабільності власних валют долару та євро «адепти» ринкової економіки - США та країни Свросоюзу [3, с. 133-134]. Також варто при цьому пригадати досвід більш успішних країн-сусідів із колишнього «соцтабору» зі стабілізації економіки, де визначальне місце належало саме фіксації курсу національних валют Польщі, Болгарії, країн Балтії тощо. Зокрема, стосовно прив'язки до введення євро латвійського лата до валютного кошика Спеціальних прав запозичення (Special Drawing Rights, SDR) та до євро у 2005-2013 pp., литовського літа у 1994-2002 рр. до долара та у 2002-2014 pр. - до євро, естонської крони до марки Німеччини та до євро в подальшому.

Нерозвиненість ринкових механізмів регулювання економіки зумовлює й те, що на відміну від переважної більшості країн, де падіння курсу національної валюти призводить до збільшення споживання товарів внутрішнього виробництва через зростання цін на імпорт і, відповідно, за рахунок активізації внутрішньої підприємницької діяльності певною мірою сприяє подоланню кризової ситуації, в умовах України це призводить до майже автоматичного перерахунку цін у рази спочатку на імпортні, а потім, навздогін, і на вітчизняні товари, ще більше посилюючи кризові явища. Таким чином, реалізація в сучасних умовах органами державного управління політики підтримки національного виробника, тобто практично розвитку національної економіки та повернення вітчизняних товарів на внутрішній ринок [32; 33]. 
3 іншого боку, реальне занепокоєння у даному питанні викликає позиція найвищого керівництва держави стосовно відсутності «необхідності стримувати курс гривні» i, своєю чергою, заяви стосовно того, що «зміцнення курсу гривні в 2019 році призвело до падіння економіки» $\mathrm{i}$ «здорова інфляція» дасть підприємствам зростати, на наше переконання, $\epsilon$ підготовкою грунту для чергових урядових експериментів, які у представленому «інфляційно-девальваційному циклі» можуть знов стати причиною «обвалу» курсу національної валюти [34-36]. При цьому неважко спрогнозувати, що серед основних причин цього чергового «обвалу гривні» знов будуть визнані не зростання споживчих цін i, відповідно, зниження купівельної спроможності української валюти та інші внутрішні проблеми й урядові прорахунки, а зовнішні чинники, зокрема пандемія COVID-19.

Показовою є й ситуація зі звільненням з посади голови Нацбанку А. Смолія, який розділяв позицію дослідників, до яких належить і автор, стосовно того, що «стабільна та невисока інфляція сприяє стійкому економічному зростанню, кредитуванню, зміцненню довіри до національної валюти, а також дає змогу якісно планувати майбутнє бізнесу та громадянам» [37].

Занепокоєність у цьому плані разом з автором та низкою вітчизняних науковців і представників підприємницького середовища розділяють і експерти міжнародного рівня, якими підкреслюється, що «впливові політики в оточенні президента В. Зеленського керуються небезпечною ідеєю про те, що висока інфляція і значна девальвація національної валюти нібито сприяють економічному зростанню» й якщо подібна політика буде продовжена, вона сповільнить економічне зростання [38]. Зрозумілим є також і те, що процес супроводжуватиметься черговим зниженням рівня життя населення країни та цілою низкою інших негативних соціально-економічних наслідків.

\section{Висновки}

Розглядаючи один із визначальних, на нашу думку, чинників реального знецінення гривні - зростання споживчих цін, маємо зазначити, що, звичайно, у їх основі лежить цілий комплекс причин внутрішнього та зовнішнього характеру, але основними, на наше переконання, $\epsilon$ нерозвиненість ринкових механізмів у економіці України, а також популізм та непрофесійність дій урядових структур, які не лише не в змозі протидіяти інфляційним процесам, а й певною мірою їм сприяють.

Вітчизняними експертами 3 економічної безпеки неодноразово підкреслювалося, що важливо домогтися, щоб національні гроші виконували функції накопичення, обслуговуючи потреби збереження фінансових ресурсів бізнесу та домогосподарств, однак це залежить не лише від банківської системи, а й великою мірою від економічної 
політики уряду [3, с. $131 ; 5$, с. 46; 39, с. 99]. I важливим у цьому плані $\epsilon$ розуміння того, що відмова від економічного розвитку та піднесення добробуту під впливом помилкового уявлення про монетарний характер інфляції становить серйозну загрозу можливості реалізації розвитку економіки [40, с. 398].

Українська економічна реальність потребує дійсно професійного антикризового державного управління, спрямованого на захист національних інтересів. Тому єдиною перспективою ми бачимо лише реалізацію скоординованого комплексу дій із боку Кабінету Міністрів, НБУ, Міністерства фінансів, Мінекономіки, Антимонопольного комітету, інших органів державного управління, спрямованих на стабілізацію національної грошової одиниці та протидію зниженню іiї купівельної спроможності, тобто припинення процесу постійного необгрунтованого зростання споживчих цін та недопущення подальших «обвалів» обмінного курсу. Інакше через відсутність системного антикризового управління зазначений «інфляційно-деномінаційний механізм» продовжить руйнацію вітчизняної економіки.

Ми, звичайно, не маємо на увазі здійснення адміністративного регулювання цін із боку держави, але від моніторингу їхньої динаміки та реалізації засобів антимонопольного регулювання державні органи ще ніким не звільнялися. Як свого часу зазначалося автором, ми повною мірою обгрунтовано можемо вважати національну валюту України гривню «квазівалютою» доти, доки вона не буде повною мірою виконувати усі притаманні повноцінній грошовій одиниці функції, включаючи і функцію збереження вартості [10, с. 70].

Ураховуючи наведене, у зв'язку 3 тим, що грошово-кредитній політиці належить одне 3 ключових місць у формуванні, розподілі і перерозподілі національного доходу, в організації планування та регулювання грошового обороту, активізації економічних процесів, подолання $з$ iї боку загроз економічній безпеці України, а також забезпечення стабільності і надійності національної грошової одиниці має стати одним 3 основних напрямів антикризової стратегії економічного розвитку Української держави.

\section{Список використаних джерел:}

1. Про національну безпеку України : Закон України від 21.06.2018 № 2469-VIII / Верховна Рада України. URL: http://zakon.rada.gov.ua/laws/show/2469-19 (дата звернення: 01.12.2020).

2. Економічна безпека : навчальний посібник / за ред. З.С. Варналія. Київ : Знання, 2009. $647 \mathrm{c.}$

3. Мунтіян В.І. Економічна безпека України : монографія. Київ : КВІЦ, 1999. 464 с.

4. Курс долара продовжив зростання. Главред : вебсайт. URL: http://glavred.info/ ekonomika/ekspert-obyasnil-prichiny-rezkogo-padeniya-kursa-grivny-270331.html

5. Шлемко В.Т., Бінько І.Ф. Економічна безпека України: сутність і напрямки забезпечення : монографія. Київ : НІСД, 1997. 144 с. 
6. Эксперт объяснил причины резкого падения курса гривны. Главред : вебсайт. URL: http://glavred.info/ekonomika/ekspert-obyasnil-prichiny-rezkogo-padeniya-kursagrivny-270331.html

7. Эксперт назвал истинные причины девальвации гривны. Контракты.иа : вебсайт. URL: http://kontrakty.ua/article/81455 (дата звернення: 01.12.2020).

8. Експерт: Гривня девальвує через безконтрольну емісію. Forum : вебсайт. URL: http://for-ua.com/article/1069538 (дата звернення: 01.12.2020).

9. В чем причины очередного падения гривны? Informator : вебсайт. URL: http://www.informator.su/v-chem-prichinyi-ocherednogo-padeniya-grivnyi/ (дата звернення: 08.01.2015).

10. Мірошниченко О.В. Знецінення національної грошової одиниці як загроза економічній безпеці України. Вісник економічної науки Украӥни. 2014. № 3(27). C. 65-71.

11. Знецінення національної грошової одиниці: чому падає гривня? Україна молода. 2015. 26 лютого. № 3.

12. Мірошниченко О., Лазарев Д. Проблема знецінення національної грошової одиниці України та шляхи ії стабілізації. Стан, проблеми та перспективи розвитку національної економіки : матеріали Міжнар. наук.-практ. конф. Одеса: ЦЕДР, 2015. C. 66-70.

13. Мірошниченко О.В. Питання економічної кризи треба вирішувати в Україні. Николаевский обозреватель : вебсайт. URL: http://obzor.mk.ua/nikolaevskie-novosti/ 10099-pitannya-ekonomchnoyi-krizi-treba-virshuvati-v-ukrayin.html (дата звернення: 01.12.2020).

14. Мірошниченко О.В. Постійне повторення прем'єром словосполучення «світова фінансова криза» наносить економіці України більшої шкоди, ніж сама криза. Хрещзатик. 2008. 12 травня. № 81(3297).

15. Мірошниченко О.В. Основними рисами, що характеризують діяльність уряду Яценюка, залишаються всебічний непрофесіоналізм та хворобливий нарцисизм. Экономика \& политика : вебсайт. URL: http://kiev.econompolit.ru/Article.aspx?id= 32344\&id_line=29 (дата звернення: 01.12.2020).

16. Хаєцька О.П., Вертелецький М.В. Аналіз динаміки ВВП України та інших країн світу. Ефективна економіка. URL: http://www.economy.nayka.com.ua/pdf/ 1_2018/60.pdf (дата звернення: 01.12.2020).

17. Панібратов О. Високі темпи економічного зростання в Україні: реальність чи міф? Лабораторія законодавчих ініціатив : вебсайт. URL: https://parlament.org.ua/ 2004/10/11/visoki-tempi-ekonomichnogo-zrostannya/ (дата звернення: 01.12.2020).

18. Без сигналу від Тимошенко дані про ВВП не оприлюднять. ТСН : вебсайт. URL: https://tsn.ua/groshi/bez-signalu-vid-timoshenko-dani-pro-vvp-ne-oprilyudnyat.html (дата звернення: 01.12.2020).

19. Деньги, банковское дело и денежно-кредитная политика / Э.Дж. Доллан и др. ; под. общ. ред. В. Лукашевича. Ленинград : Автокомп, 1991. 448 с.

20. Макконнелл К.Р., Брю С.Л. Экономикс: принципы, проблемы и политика. Киев : Хагар-Демос, 1993. 785 с.

21 Тарасевич Л.С., Гребенников П.И., Леусский А.И. Макроэкономика. Москва : Высшее образование, 2006. 654 с.

22. Мищенко С.В. Современные проблемы теории денег и денежного обращения : монография. Киев : Центр науч. исслед. НБУ, Ун-т банк. дела, 2011. 230 с.

23. Гриценко А. Представницька теорія грошей. Вісник Національного банку Украӥни. 2005. № 7. С. 9-13.

24. Румянцева Е.Е. Новая экономическая энциклопедия ; 3-е изд. Москва : ИНФРА-М, 2008. $826 \mathrm{c.}$ 
25. Маркс К. Капитал. Критика политической экономии. Москва : Политиздат, $1973.907 \mathrm{c}$

26. Деньги, кредит, банки / под ред. проф. О.И. Лаврушина ; 8-е изд. Москва : КНОРУС, 2009. $560 \mathrm{c.}$

27. Экономическая и национальная безопасность / под ред. Е.А.Олейникова. Москва : Экзамен, 2005. 768 с.

28. Гонтарева нагадала депутатам, що Нацбанк не відповідає за курс гривні. УНIАН : вебсайт. URL: https://www.unian.ua/economics/finance/ 1256621-gontarevanatsbank-ne-vidpovidae-za-kurs-grivni.html (дата звернення: 01.12.2020).

29. Конституція України : Закон України від 28 червня 1996 р. № 254к/96-ВР / Верховна Рада України. Відомості Верховної Ради Украӥни. 1996. № 30.

30. Про Національний банк України : Закон України від 20 травня 1999 p. № 679-XIV / Верховна Рада України. URL: http://zakon.rada.gov.ua/laws/show/679-14 (дата звернення: 01.12.2020).

31. Мірошниченко О.В. Уряд повинен перестати бути інструментом для викачування грошей 3 економіки і має бути сформований 3 відповідальних професіоналів. Від Майдану-2004 до Свромайдану-2014: десятиріччя поразок $i$ перемог : збірник публікацій. Миколаїв : ІПД, 2014. С. 102.

32. Прем'єр-міністр Денис Шмигаль розповів про програму економічного відновлення України. Урядовий портал : єдиний вебпортал органів виколавчої влади України. URL: https://www.kmu.gov.ua/news/premyer-ministr-denis-shmigal-rozpovivpro-programu-ekonomichnogo-vidnovlennya-ukrayini (дата звернення: 01.12.2020).

33. Основним пріоритетом забезпечення національної безпеки України повинно стати відродження ії виробничого потенціалу. Народне слово. 2009. № 11(431).

34. Зеленський не бачить необхідності стримувати курс гривні. Радіо Свобода: вебсайт. URL: https://www.radiosvoboda.org/a/news-zelenskyj-kurs-hryvni/ 30706152.html (дата звернення: 01.12.2020).

35. Міністр економіки назвав зміцнення гривні причиною падіння економіки. Економічна правда : вебсайт. URL: https://www.epravda.com.ua/news/2020/07/22/ 663255/ (дата звернення: 01.12.2020).

36. «Низька інфляція - це катастрофа». Чому міністр економіки хоче, щоб ціни зростали швидше. Економічна правда : вебсайт. URL: https://www.epravda.com.ua/ publications/2020/07/13/662865/1 (дата звернення: 01.12.2020).

37. Відставка Смолія спровокувала стрибок курсу валют. Главком : вебсайт. URL: https://glavcom.ua/economics/finances/vidstavka-smoliya-sprovokuvala-stribokkursu-valyut-690619.html (дата звернення: 01.12.2020).

38. Aslund A. Zelenskyy's bad economics: Inflation and devaluation will not help Ukraine grow. Atlantic council : вебсайт. URL: https://www.atlanticcouncil.org/blogs/ ukrainealert/zelenskyys-bad-economics-inflation-and-devaluation-will-not-help-ukrainegrow/ (дата звернення: 01.12.2020).

39. Мірошниченко О.В. Економічна безпека України: стан і дослідження питання (погляд скрізь 20-річчя незалежності). Вісник економічної науки Украӥни. 2012. № 2(22). С. 97-101.

40. Экономическая безопасность России / под ред. В.К. Сенчагова. Москва : Бином, 2010. 815 с.

\section{References:}

1. Pro natsional'nu bezpeky Ukrayiny: Zakon Ukrayiny vid 21.06.2018 № 2469-VIII [Law of Ukraine «On National Security of Ukraine» of June 21, 2018 № 2469-VIII].

2. Varnaliy Z.S. (ed.) (2009) Ekonomichna bezpeka [Economic security]. Kyiv: Znannya. (in Ukrainian) 
3. Muntian, V.I. (1999) Ekonomichna bezpeka Ukrayiny [Economic security of Ukraine]. Kyiv: KVIC. (in Ukrainian)

4. Kurs dolara prodovzhyv zrostannya [The dollar continued to rise]. Available at: http://glavred.info/ekonomika/ekspert-obyasnil-prichiny-rezkogo-padeniya-kursa-grivny270331.html (accessed 6 December 2020).

5. Shlemko V.T., Binko I.F. (1997) Ekonomichna bezpeka Ukrayiny: sutnist' i napryamky zabezpechennya [Economic security of Ukraine: essence and directions of providing]. Kyiv: NISS. (in Ukrainian)

6. Ekspert ob»yasnil prichiny rezkogo padeniya kursa grivny [The expert explained the reasons for the sharp drop in the hryvnia exchange rate]. Available at: http://glavred.info/ekonomika/ekspert-obyasnil-prichiny-rezkogo-padeniya-kursa-grivny270331.html (accessed 6 December 2020).

7. Ekspert nazval istinnyye prichiny deval'vatsii grivny [The expert named the true reasons for the devaluation of the hryvnia]. Available at: http://kontrakty.ua/article/81455 (accessed 6 December 2020).

8. Ekspert: Hryvnya deval'vuye cherez bezkontrol'nu emisiyu [Expert: The hryvnia devalues due to uncontrolled issuance]. Available at: http://for-ua.com/article/1069538 (accessed 6 December 2020).

9. V chem prichiny ocherednogo padeniya grivny? [What are the reasons for the next drop in the hryvnia?]. Available at: http://www.informator.su/v-chem-prichinyiocherednogo-padeniya-grivnyi/ (accessed 6 December 2020).

10. Miroshnychenko O.V. (2014) Znetsinennya natsional'noyi hroshovoyi odynytsi yak zahroza ekonomichniy bezpetsi Ukrayiny [Depreciation of the national monetary unit as a threat to the economic security of Ukraine]. Visnyk ekonomichnoi nauki Ukrainy, no. 3(27), pp. 65-71.

11. Miroshnychenko O.V. (2015) Znetsinennya natsional'noyi hroshovoyi odynytsi: chomu padaye hryvnya? [Depreciation of the national currency: why is the hryvnia falling?]. Ukrayina moloda, no. 3.

12. Miroshnychenko O., Lazarev D. (2015) Problema znetsinennya natsional'noyi hroshovoyi odynytsi Ukrayiny ta shlyakhy yiyi stabilizatsiyi [The problem of devaluation of the national currency of Ukraine and ways of its stabilization]. Status, problems and prospects of the national economy '15: Mizhnarodna naukovo-praktychna konferentsiya International scientific-practical conference, pp. 66-70. Odessa: CEDR.

13. Miroshnychenko, O.V. (2008) Pytannya ekonomichnoyi kryzy treba vyrishuvaty v Ukrayini [The issue of the economic crisis must be resolved in Ukraine]. Available at: http://obzor.mk.ua/nikolaevskie-novosti/10099-pitannya-ekonomchnoyi-krizi-trebavirshuvati-v-ukrayin.html (accessed 6 December 2020).

14. Miroshnychenko O.V. (2008) Postiyne povtorennya prem'yerom slovospoluchennya «svitova finansova kryza» nanosyt' ekonomitsi Ukrayiny bil'shoyi shkody, nizh sama kryza [The prime minister's constant repetition of the phrase «global financial crisis» causes more damage to the economy of Ukraine than the crisis itself]. Khreshchatyk, no. 81(3297).

15. Miroshnychenko O.V. (2014) Osnovnymy rysamy, shcho kharakteryzuyut' diyal'nist' uryadu Yatsenyuka, zalyshayut'sya vsebichnyy neprofesionalizm ta khvoroblyvyy nartsysyzm [The main features that characterize the activities of the Yatsenyuk government are comprehensive unprofessionalism and painful narcissism] Ekonomika \& politika. Available at: http://kiev.econompolit.ru/Article.aspx?id= 32344\&id_line $=29$ (accessed 6 December 2020).

16. Hayetska O.P., Verteletsky M.V. Analiz dynamiky VVP Ukrayiny ta inshykh krayin svitu [Analysis of GDP dynamics in Ukraine and other countries]. Efektyvna ekonomika - 
Efficient economy. Available at: http://www.economy.nayka.com.ua/pdf/1_2018/60.pdf (accessed 6 December 2020).

17. Panibratov O. Vysoki tempy ekonomichnoho zrostannya v Ukrayini: real'nist' chy mif? [High economic growth in Ukraine: reality or myth?] Laboratoriya zakonodavchykh initsiatyv - Laboratory of Legislative Initiatives. Available at: https://parlament.org.ua/ 2004/10/11/visoki-tempi-ekonomichnogo-zrostannya/ (accessed 6 December 2020).

18. Bez syhnalu vid Tymoshenko dani pro VVP ne oprylyudnyat' [Without a signal from Tymoshenko, GDP data will not be released]. Available at: https://tsn.ua/groshi/bezsignalu-vid-timoshenko-dani-pro-vvp-ne-oprilyudnyat.html (accessed 6 December 2020).

19. Dollan E.J., Campbell C.D., Campbell R.J. (1991) Den'gi, bankovskoye delo i denezhno-kreditnaya politika [Money, banking and monetary policy]. Leningrad: Khudozhestvennaya literatura. (in Russian)

20. McConnell C.R., Brue S.L. (1993) Ekonomiks: printsipy, problemy i politika [Economics: principles, problems and politics]. Kyiv: Hagar-Demos. (in Russian)

21. Tarasevich L.S., Grebennikov P.I., Leussky A.I. (2006) Makroekonomika [Macroeconomics]. Moscow: Higher education. (in Russian)

22. Mishchenko S.V. (2011) Sovremennyye problemy teorii deneg i denezhnogo obrashcheniya [Modern problems of the theory of money and money circulation]. Kyiv: CSS NBU. (in Russian)

23. Hrytsenko A. (2005) Predstavnyts'ka teoriya hroshey [Representative theory of money]. Visnyk Natsional'noho banku Ukrayiny, no. 7, pp. 9-13.

24. Rumyantseva, E.E. (2008) Novaya ekonomicheskaya entsiklopediya [New economic encyclopedia]. Moscow: Infra-M. (in Russian)

25. Marx K. (1973) Kapital. Kritika politicheskoy ekonomii [Capital. Criticism of Political Economy]. Moscow: Politizdat. (in Russian)

26. Lavrushin O.I. (ed.) (2008) Den'gi, kredit, banki [Money, credit, banks]. Moscow: KNORUS. (in Russian)

27. Oleinikov E.A. (ed.) (2005) Ekonomicheskaya i natsional'naya bezopasnost' [Economic and national security]. Moscow: Exam. (in Russian)

28. Hontareva nahadala deputatam, shcho Natsbank ne vidpovidaye za kurs hryvni [Gontareva reminded the deputies that the National Bank is not responsible for the hryvnia exchange rate]. Available at: https://www.unian.ua/economics/finance/1256621-gontarevanatsbank-ne-vidpovidae-za-kurs-grivni.html (accessed 6 December 2020).

29. Konstytutsiya Ukrayiny, pryynyata 28.06.1996 [Constitution of Ukraine, adopted on June 28, 1996].

30. «Pro Natsional'nyy bank Ukrayiny»: Zakon Ukrayiny vid 20.05.1999 № 679-XIV [Law of Ukraine «On the National Bank of Ukraine» of May 20, 1999 № 679-XIV].

31. Miroshnychenko, O.V. (2014) The government should cease to be a tool for pumping money out of the economy and should be formed of responsible professionals. From Maidan-2004 to Euromaidan-2014: decades of defeats and victories. Mykolaiv: IAS.

32. Prem"yer-ministr Denys Shmyhal' rozpoviv pro prohramu ekonomichnoho vidnovlennya Ukrayiny [Prime Minister Denis Shmygal spoke about Ukraine's economic recovery program]. Available at: https://www.kmu.gov.ua/news/premyer-ministr-denisshmigal-rozpoviv-pro-programu-ekonomichnogo-vidnovlennya-ukrayini (accessed 6 December 2020).

33. Miroshnychenko O.V. (2009) Osnovnym priorytetom zabezpechennya natsional'noyi bezpeky Ukrayiny povynno staty vidrodzhennya yiyi vyrobnychoho potentsialu [The main priority of ensuring the national security of Ukraine should be the revival of its production potential]. Narodne slovo, no. 11(431). 
34. Zelens'kyy ne bachyt' neobkhidnosti strymuvaty kurs hryvni [Zelensky sees no need to restrain the hryvnia exchange rate]. Available at: https://www.radiosvoboda.org/a/ newszelenskyj-kurs-hryvni/30706152.html (accessed 6 December 2020).

35. Ministr ekonomiky nazvav zmitsnennya hryvni prychynoyu padinnya ekonomiky [The Minister of Economy called the strengthening of the hryvnia the cause of the economic downturn]. Available at: https://www.epravda.com.ua/news/2020/07/22/ 663255/ (accessed 6 December 2020).

36. «Nyz'ka inflyatsiya - tse katastrofa». Chomu ministr ekonomiky khoche, shchob tsiny zrostaly shvydshe [ «Low inflation is a disaster». Why the Minister of Economy wants prices to rise faster]. Available at: https://www.epravda.com.ua/publications/ 2020/07/13/662865/l (accessed 6 December 2020).

37. Vidstavka Smoliya sprovokuvala strybok kursu valyut [Smolya's resignation provoked a jump in the exchange rate]. Available at: https:/glavcom.ua/economics/ finances/vidstavka-smoliya-sprovokuvala-stribok-kursu-valyut-690619.html (accessed 6 December 2020).

38. Aslund A. Zelenskyy's bad economics: Inflation and devaluation will not help Ukraine grow. Available at: https://www.atlanticcouncil.org/blogs/ukrainealert/ zelenskyys-badeconomics-inflation-and-devaluation-will-not-help-ukraine-grow/ (accessed 6 December 2020).

39. Miroshnychenko O.V. (2012) Ekonomichna bezpeka Ukrayiny: stan i doslidzhennya pytannya (pohlyad skriz' 20-richchya nezalezhnosti) [Economic security of Ukraine: state and research of the issue (view everywhere of the 20th anniversary of independence)]. Visnyk ekonomichnoi nauki Ukrainy, no. 2(22), pp. 97-101.

40. Senchagov V.K. (ed.) (2010) Ekonomicheskaya bezopasnost' Rossii [Economic security of Russia]. Moscow: Binom. (in Russian) 